\section{Into the woods}

Encyclopedia of Forest Sciences edited by Jeffery Burley, Julian Evans \& John A. Youngquist

Academic Press: 2004. 2,400 pp. £569, \$875

\section{Colin Tudge}

The past few hundred years of industrialization have left the world with a series of what can reasonably be called crises: of climate, food, and cities that are ever more out of control. All of these involve trees, in one way or another. Get forestry right, and a lot more will follow.

There is much to encourage in the Encyclopedia of Forest Sciences, which provides an excellent summary of current ideas and practice. The modern science of forestry is often breathtaking. On the grandest scale, satellites can measure the height of forests to within about $30 \mathrm{~cm}$, monitoring the growth and the density of leaves over entire continents - a task that would take lifetimes of work from the ground. The exchange of gases and volatiles from the canopy and roots is measured around the clock and the calendar. Hectares of tropical forest have been starved of most of their water, by covering the ground and draining the rain away, to measure the effects of drought.

From such measures (and a great deal of computer power), the effects of global warming can be modelled. As carbon dioxide increases, so too should photosynthesis (which uses it up), and there is now experimental evidence for this. But temperature should also rise, increasing respiration, which slows growth, and harming trees that are not adapted to a hotter climate. As they die, there is a short-term net release of carbon dioxide.

Global warming can increase rainfall in high latitudes and the tropics yet reduce it in the subtropics. But the effects will be patchy

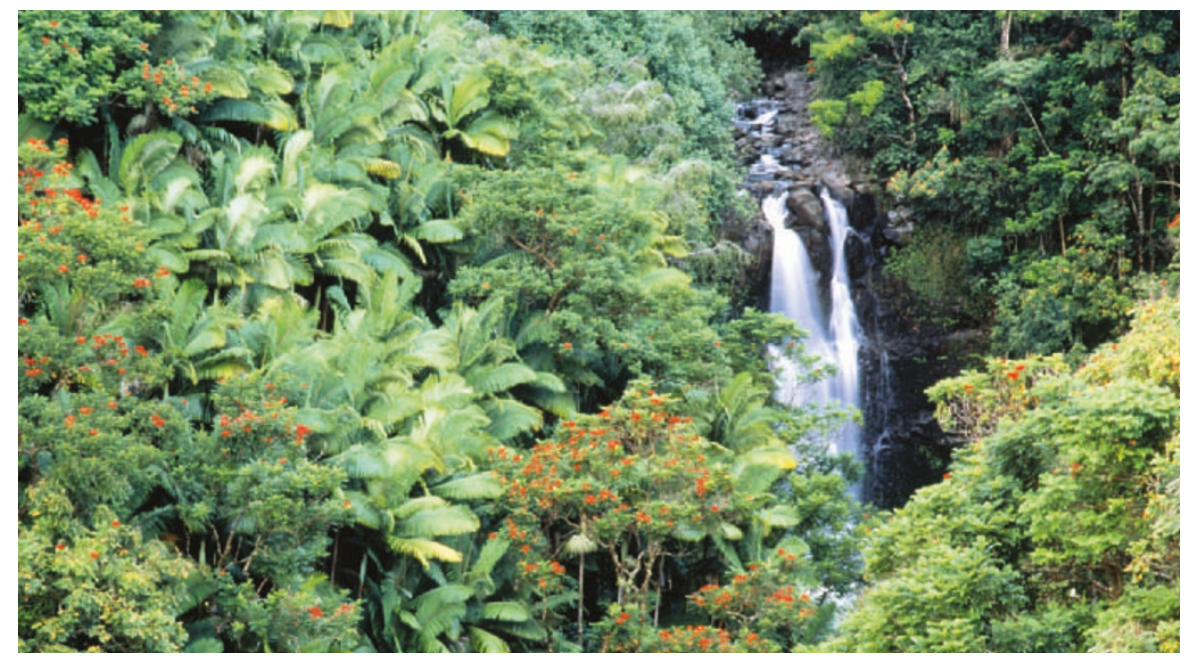

A green solution: maintaining forests, like this one in Hawaii, can help to counteract climate change.

and erratic; in particular, El Niño is a huge and unpredictable player. Where there is drought, trees will stop growing and again become net releasers of carbon dioxide. More heat means more drying, which means more fires - another major source of carbon dioxide (with more released from the bare ground left behind). If leaf litter is left in situ, the chance of fire increases; if it is removed, nitrogen is lost too and soil fertility is reduced. It is a difficult balance to strike, but there is no doubt that trees ameliorate climate change. The world needs more trees.

On a smaller scale, biologists can now sample the DNA in the cambial cells of wild trees, just beneath the bark, so they can track the loss of genetic diversity under different logging regimes. Forestry practice is still, in large part, craft. Sustainable harvesting, the great desideratum, is largely governed by good sense and rules of thumb. This is as is should be; as the world's agriculture shows, we abandon common sense at our peril. But the more science that is deployed in the service of craft and sense, the better.

\section{New in paperback}

\section{Galileo's Finger: The Ten Great Ideas} of Science

by Peter Atkins

Oxford University Press, £8.99

"This is a charming and ambitious book that I would not hesitate to recommend as a gift for a young person on the threshold of a scientific career." Frank Wilczek, Nature 422, 377-378 (2003).

\section{Eurekas and Euphorias: The Oxford Book of Scientific Anecdotes}

by Walter Gratzer

Oxford University Press, £8.99, \$15.95

A book of scientific anecdotes that "cover the entire range of human genius, folly, character and accident". Oliver Sacks, Nature 419, 786 (2002).

\section{The Extravagant Universe: Exploding} Stars, Dark Energy and the Accelerating Cosmos

by Robert P. Kirshner

Princeton University Press, £12.95

The story of the acceleration of the Universe "is related with verve and good humour". Sean Carroll, Nature 419, 784-785 (2002).

The Solar Economy: Renewable Energy for a Sustainable Global Future by Hermann Scheer

Earthscan, £17.99, \$24.95

\section{Safe Food: Bacteria, Biotechnology, and Bioterrorism}

by Marion Nestle

University of California Press, £10.95, \$15.95
Forestry has an ambivalent relationship with farming. Both are vital. Both determine landscape. Often they have been in conflict. But they can operate beautifully in harmony through the much neglected but highly promising pursuit of agroforestry. Trees are grown mainly for timber and shade, but they are also - or could be - huge producers of food and fodder in their own right. Agroforestry would be a much more effective employer in the developing world than the spreading estates of soya, coffee and other industrialized commodity crops that are now the rage. And viable agrarian economies have never been needed more, to relieve the swelling cities.

In one crucial respect, foresters now have a significant edge over farmers. Consumers can eat only so much food, and farmers always face the spectre of overproduction, which is only slightly less destructive than crop failure. I view the continuing emphasis on productivity in agricultural science (epitomized by the zeal for biotech) as a kind of lunacy, although it is highly profitable for its controllers.

But there need be no ceiling on the raising of trees. Flourishing forest is a carbon sink. Trees used as fuel are carbon neutral. Much more timber could be used in construction, as protected teak doesn't sag like plasticine when hot, as steel does. Of course, it takes extra energy (and hence more carbon) to turn a tree into usable timber, but it takes 12 times as much to produce steel to do the same job. If carbon taxes are applied to building materials, which surely is desirable, then the market for timber would be insatiable.

Forestry has always been at the heart of human economies and now it seems more important than ever. But bringing its ideas together into a satisfying whole is not easy. This encyclopedia does the job triumphantly. If you are at all involved with trees, you should have a copy. And who isn't? Colin Tudge is a writer based in Oxfordshire, UK. His latest book, on farming, is So Shall We Reap. 